\title{
Modeling and Control of Laptop Computer Voltage Regulator Module with Multiple Power Sources
}

\author{
Ravindranath Tagore Yadlapalli ${ }^{*}$, Anuradha Kotapati ${ }^{2}$ \\ ${ }^{1}$ Department of Electrical and Electronics Engineering, RVR \& JC CE, Andhra Pradesh 522019, India \\ ${ }^{2}$ Department of Electrical and Electronics Engineering, VNR VJIET, Hyderabad 500090, India
}

Corresponding Author Email: tagore@rvrjc.ac.in

https://doi.org/10.18280/jesa.530313

Received: 5 March 2020

Accepted: 10 May 2020

Keywords:

fuel cell, controllers, synchronous rectification $(S R)$

\begin{abstract}
This paper presents the modeling and control of Air Breathing Fuel Cell (ABFC) and solar PV based power system for feeding the voltage regulator module of a laptop computer. The MATLAB modeling comprises of power sources as well as power conditioning units (PCUs). The different power sources under consideration are ABFC stack and solar PV module feeding the PCUs. The quadratic buck converter (QBC) and boost converter combination are used as a power conditioning unit (PCU). The average current mode control (ACMC) based QBC enables good steady state and dynamic voltage regulations. The perturb and observe $(\mathrm{P} \& \mathrm{O})$ algorithm is used for maximum power tracking of solar PV panel. The efficiency analysis of ABFC power system and PV module power system are represented.
\end{abstract}

\section{INTRODUCTION}

A Fuel Cell is an electrochemical device that produces electrical energy without the need of an intermediate stage [1-3]. It uses hydrogen in the electro-chemical reaction process and the byproducts are water, heat and electricity. The chemical reactions at anode and cathode are given by Eqns. (1)-(3).

$$
\begin{gathered}
2 \mathrm{H}_{2} \rightarrow 4 \mathrm{H}^{+}+4 \mathrm{e}^{-} \\
\mathrm{O}_{2}+4 \mathrm{H}^{+}+4 \mathrm{e}^{-} \rightarrow 2 \mathrm{H}_{2} \mathrm{O} \\
2 \mathrm{H}_{2}+\mathrm{O}_{2} \rightarrow 2 \mathrm{H}_{2} \mathrm{O}+\text { Electricity }+ \text { Heat }
\end{gathered}
$$

The cells that extract oxygen from the ambient air through passive means for cathode reaction are named as "airbreathing” fuel cells [2]. In Air Breathing Fuel Cell (ABFC), the oxygen supply to cathode happens from free convection air flow whereas hydrogen to anode comes from compressed gas cylinders. The schematic of an ABFC is shown in Figure 1 .

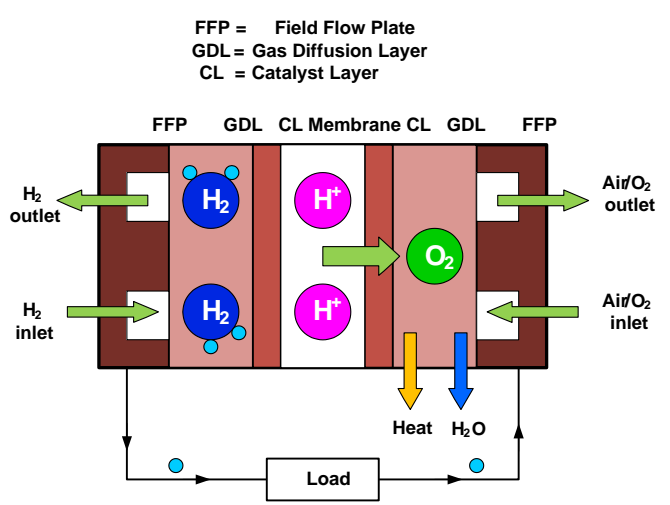

Figure 1. Schematic of ABFC
There is no need of auxiliary fan in ABFCs. This reduces the overall system volume and weight which is useful for laptop computer voltage regulator module (VRM) applications. Moreover, air is preferable than oxygen for curtailing the inflammable nature that is arising from hydrogen. A single ABFC typically achieves $0.5 \mathrm{~V}$ to $0.7 \mathrm{~V}$. For electronic devices like laptops, which require relatively high power, a fuel cell stack is obtained by adding several cells in series. The Switched Mode Power Supplies (SMPS) are prominent because they have high packing density in addition to good efficiency. Recent advances in integrated circuitries demand for high conversion ratio's from dc-dc converters to produce desired output voltages of $1 \mathrm{~V}, 1.5 \mathrm{~V}$, $3.3 \mathrm{~V}$ and $12 \mathrm{~V}$. The buck converter is not pertinent for such applications due to minimum turn-on time necessity of the switch. Its operation is also limited to lower dc-dc converter switching frequencies [4, 5]. On the other hand, cascade connection downside is the low efficiency even though it has a positive scope of achieving high conversion ratios. Therefore, the preferable one is the quadratic buck converter (QBC). On the other hand, it is always economical to use multiple sources of energy. This paper presents the ABFC and solar PV based power system for powering the laptop computer VRM. Here, the fuel cell is the primary source of energy and the solar power is used whenever it is available [6]. In ABFC power system, the QBC controls the unregulated output voltage of the ABFC fuel cell stack using average current mode control (ACMC) technique. The QBC converts $19 \mathrm{~V}$ obtained from the fuel stack to $1 \mathrm{~V}$, acts as a laptop computer VRM. In PV power system the boost converter is used for maximum power tracking. The QBC converts the intermediate voltage level obtained at the output of boost converter to the desired voltage of $1 \mathrm{~V}$. The paper organization is as follows; section 2 presents the overall view of the ABFC and PV module power system, section 3 describes the power conditioning units (PCUs) along with 
their control strategies, the simulation results and conclusions are given in section 4 and section 5 .

\section{MODELING OF THE OVERALL ABFC AND PV MODULE POWER SYSTEM}

The power system model is constituted by:

- Modeling of an ABFC stack.

- Modeling of PV module.

- Modeling of QBC.

Figure 2 shows the proposed schematic of the ABFC power system. The following sections give the design and modelling of each block. The simulation results are presented at each stage to demonstrate the functionality of the models.

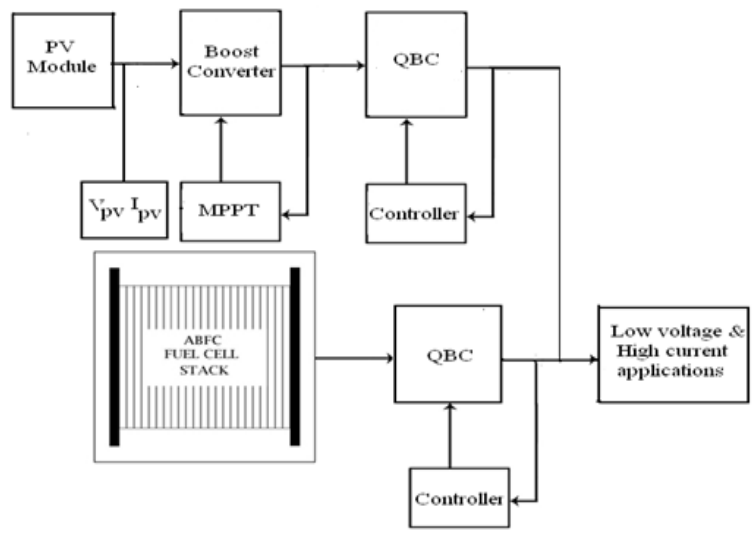

Figure 2. Proposed ABFC and PV module power system

\subsection{ABFC stack model}

At standard state conditions of $25^{\circ} \mathrm{C}$ and 1 atm $(101.25$ $\mathrm{kPa}$ ), the standard potential from a hydrogen/oxygen fuel cell is around $1.229 \mathrm{~V}$. However, the cell potential drops from equilibrium value due to irreversible losses. The different irreversible losses are activation, ohmic, and concentration losses. The ABFC output voltage [7-9] is given by Eqns. (4) (10).

$$
\begin{gathered}
\mathrm{V}_{\text {Fuelcell }}=\mathrm{V}_{\text {Opencircuit }}-\Delta \mathrm{V}_{\text {Activation }} \\
-\Delta \mathrm{V}_{\text {Ohmic }}-\Delta \mathrm{V}_{\text {Concentration }} \\
\mathrm{V}_{\text {Opencircuit }}=\mathrm{V}_{\text {Nernst }}-\mathrm{V}_{\text {Cross }} \\
\mathrm{V}_{\text {potentialNernst }}=1.482-0.000845 * \mathrm{~T} \\
+0.0000431 * \mathrm{~T} * \ln \left(\rho_{\mathrm{H}_{2}} * \rho_{\mathrm{O}_{2}}{ }^{0.5}\right) \\
\mathrm{V}_{\text {Cross }}=\frac{\mathrm{RT}}{\alpha \mathrm{F}} \ln \left(\frac{\mathrm{i}_{\text {Cross }}}{\mathrm{i}_{0}}\right) \\
\rho_{\mathrm{H}_{2}}=\frac{0.5 \mathrm{P}_{\mathrm{H}_{2}}}{\exp \left(\frac{1.653 * \mathrm{i}}{\mathrm{T}_{\mathrm{ADP}}^{1.334}}\right)}-\mathrm{P}_{\text {Sat }}
\end{gathered}
$$

$$
\rho_{\mathrm{O}_{2}}=\frac{\mathrm{P}_{\mathrm{O}_{2}}}{\exp \left(\frac{4.192 * \mathrm{i}}{\mathrm{T}_{\mathrm{GDP}}^{1.334}}\right)}-\mathrm{P}_{\mathrm{Sat}}
$$

$\mathrm{P}_{\text {Sat }}=10^{\left(-2.1794+0.02953 * \mathrm{~T}-9.1837 * 10^{-5} * \mathrm{~T}^{2}+1.4454 * 10^{-7} * \mathrm{~T}^{2}\right)}$

The activation loss is presented using Eq. (11).

$$
\Delta \mathrm{V}_{\text {Activation }}=\frac{\mathrm{RT}}{\alpha \mathrm{F}} \ln \left(\frac{\mathrm{i}}{\mathrm{i}_{0}}\right)
$$

The ABFC activation losses are given by:

$$
\Delta \mathrm{V}_{\text {Activation }}=\frac{\mathrm{RT}}{\alpha \mathrm{F}} \ln \left(\frac{\mathrm{i}+\mathrm{i}_{\mathrm{cr}}}{\mathrm{i}_{0}}\right)
$$

The ohmic losses are modelled by Eq. (13) and Eq. (18).

$$
\begin{gathered}
\Delta \mathrm{V}_{\mathrm{Ohm}}=\mathrm{i}^{*} \mathrm{r}_{\mathrm{Ohm}} \\
\mathrm{r}_{\mathrm{Ohm}}=\mathrm{r}_{\text {resis tan ceAnode }}+\mathrm{r}_{\text {resis tan ceCathode }} \\
+\mathrm{r}_{\text {resis tan ceIonic }}+\mathrm{r}_{\text {resis tan ceContact }} \\
\mathrm{r}_{\text {resistan ceAnode }}=\frac{\rho_{\mathrm{GDL} * \mathrm{~L}_{\mathrm{GDL}}}}{\mathrm{A}_{\text {cellarea }}}+\frac{\rho_{\mathrm{Gr} * \mathrm{~L}_{\mathrm{Gr}}}}{\mathrm{A}_{\text {cellarea }}} \\
\mathrm{r}_{\text {resistan ceCathode }}=\frac{\rho_{\mathrm{GDL} * \mathrm{~L}}}{\mathrm{~A}_{\text {cellarea }}}+\frac{\rho_{\mathrm{Gr} * \mathrm{~L}}}{\mathrm{~A}_{\text {cellarea }}} \\
\mathrm{r}_{\text {Ionic }}=\frac{\mathrm{L}_{\mathrm{Membrane}}}{\sigma \mathrm{A}_{\mathrm{C}}}
\end{gathered}
$$

$\sigma=(0.005169 * \lambda-0.00326) * \exp \left(1268\left(\frac{1}{303}-\frac{1}{\mathrm{~T}}\right)\right)$

Eq. (19) presents the concentration losses given by:

$$
\Delta \mathrm{V}_{\text {ConcentrationLosses }}=\frac{\mathrm{RT}}{\mathrm{nF}}\left(1+\frac{1}{\alpha}\right) \ln \left(\frac{\mathrm{i}_{\mathrm{L}}}{\mathrm{i}_{\mathrm{L}}-\mathrm{i}}\right)
$$

\subsection{Photovoltaic module}

Figure 3 gives the solar cell [10] the equivalent circuit. The Iph, Rsh and Rse represent the cell photo current, shunt and series resistances respectively.

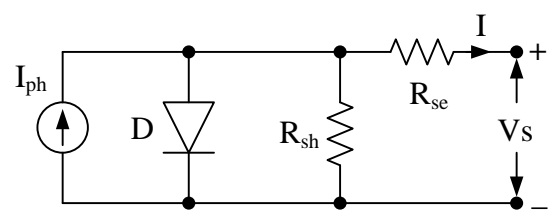

Figure 3. Equivalent circuit of PV cell 
The photo current of PV module is given by Eq. (20).

$$
\mathrm{I}_{\text {photon, } \mathrm{PV}}=\left[\mathrm{I}_{\mathrm{scr}, \mathrm{PV}}+\mathrm{K}_{\mathrm{i}}(\mathrm{T}-298)\right] * \frac{\mathrm{G}}{1000}
$$

The reverse saturation current is shown by Eq. (21).

$$
\begin{aligned}
& \mathrm{I}_{\text {reversesaturation,PV }}= \\
& \mathrm{I}_{\text {scr,PV }} /\left[\exp \left(\mathrm{qv}_{\mathrm{oc}} / \mathrm{N}_{\mathrm{s}} \mathrm{KaT}\right)-1\right]
\end{aligned}
$$

The saturation current $\mathrm{I}_{O}$ is given by Eq. (22).

$$
\begin{aligned}
& I_{\text {saturation,PV }}=I_{\text {reversesaturation,PV }} \\
& {\left[\frac{\mathrm{T}}{\mathrm{T}_{\mathrm{rs}}}\right]^{3} \exp \left[\frac{\mathrm{q}_{\mathrm{e}} * \mathrm{E}_{\mathrm{g}}}{\mathrm{aK}}\left\{\frac{1}{\mathrm{~T}_{\mathrm{rs}}}-\frac{1}{\mathrm{~T}}\right\}\right]}
\end{aligned}
$$

The PV module current output is represented by Eq. (23).

$$
\begin{aligned}
& \mathrm{I}_{\mathrm{PV}}=\mathrm{N}_{\text {parallel }} * \mathrm{I}_{\mathrm{ph}, \mathrm{PV}}-\mathrm{N}_{\text {parallel }} * \mathrm{I}_{\text {saturation }} \\
& {\left[\exp \left\{\mathrm{q}_{\mathrm{e}} *\left(\mathrm{~V}_{\mathrm{PV}}+\mathrm{I}_{\mathrm{PV}} \mathrm{R}_{\mathrm{S}}\right) / \mathrm{N}_{\text {series }} \mathrm{aKT}\right\}-1\right]}
\end{aligned}
$$

\section{DESIGN OF PCU AND CONTROLLER}

\subsection{Boost converter with MPPT}

Figure 4 highlights the schematic of the boost converter with its input-output voltage relation is given by Eq. (24).

$$
\mathrm{V}_{0}=\frac{\mathrm{V}_{\mathrm{S}}}{(1-\mathrm{D})}
$$

Perturb \& Observe (P\&O) algorithm [10] is widely used MPPT technique for boost converter. P \& O MPPT algorithm inscribes that for small perturbations in panel voltage, $\Delta \mathrm{P}$ is positive, then the desired path is in the direction of MPP, hence the duty cycle $(\delta)$ has to be incremented and continue in the same way. If $\Delta \mathrm{P}$ is negative, then the path deviates from MPP, hence the duty cycle $(\delta)$ has to be decremented. If $\Delta \mathrm{P}$ is zero, it indicates MPP. The boost converter is prominent for MPPT.

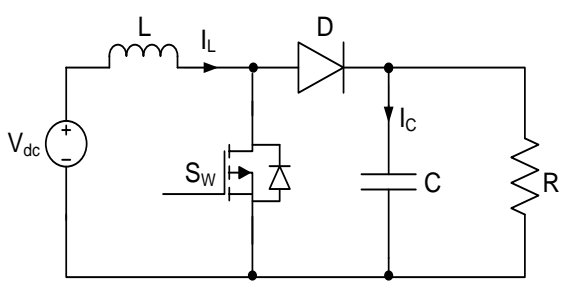

Figure 4. Schematic of boost converter

\subsection{QBC with ACMC}

QBC is used as a PCU $[11,12]$ whose schematic is shown in Figure 5 along with its voltage conversion ratio represented by Eq. (25).

$$
\mathrm{M}(\mathrm{D})=\frac{\mathrm{V}_{\mathrm{O}}}{\mathrm{V}_{\text {in }}}=\mathrm{D}^{2}
$$

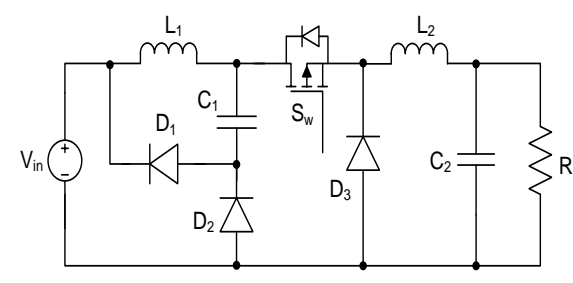

Figure 5. Quadratic buck converter

\section{SIMULATION RESULTS}

\subsection{ABFC and PV module}

The literature [7-9] gives the simulation parameters of an ABFC shown in Table 1. As represented in Figure 2 for ABFC power system, the output of ABFC stack goes to the QBC. Table 2 highlights the electrical characteristics of a 30 W PV module. In the solar PV power system, the PV module output is fed to the boost converter for MPPT. The boost converter output is given as input to the QBC. The simulation parameters of continuous conduction mode (CCM) based QBC and boost converter are tabulated in Table 3. In both converters, the CCM operation results in low losses and high efficiency.

Table 1. ABFC simulation parameters

\begin{tabular}{cl}
\hline Parameter & \multicolumn{1}{c}{ Value } \\
\hline GDL $\rho$ & $0.0017 \Omega-\mathrm{Cm}$ \\
GDL $\rho$ & $0.036 \mathrm{Cm}$ \\
Graphite $\rho$ & $0.00231 \Omega-\mathrm{Cm}$ \\
Graphite Flow Channel Thickness & $0.1 \mathrm{Cm}$ \\
Membrane Thickness & $0.0178 \mathrm{Cm}$ \\
$\lambda$ & 12 \\
icr & $3 \mathrm{~mA} / \mathrm{Cm}^{2}$ \\
Contact resistance $(\mathrm{r})$ & $30 \Omega-\mathrm{Cm}^{2}$ \\
\hline
\end{tabular}

Table 2. Electrical characteristics of $30 \mathrm{~W}$ PV module

\begin{tabular}{cc}
\hline Simulation parameter & Value \\
\hline $\mathrm{P}_{\mathrm{rated}}$ & $30 \mathrm{~W}$ \\
$\mathrm{~V}_{\mathrm{mp}}$ & $19 \mathrm{~V}$ \\
$\mathrm{~V}_{\mathrm{oc}}$ & $27.5 \mathrm{~V}$ \\
$\mathrm{I}_{\mathrm{sc}}$ & $1.83 \mathrm{~A}$ \\
$\mathrm{~N}_{\mathrm{s}}$ & 47 \\
$\mathrm{~N}_{\mathrm{p}}$ & 1 \\
\hline
\end{tabular}

Figure 6 shows the MATLAB ABFC stack model based on Eqns. (4)-(19). This model includes the activation loss, ohmic loss, mass transportation and Nernst open circuit voltage blocks for realizing the actual behaviour of the ABFC. The Polarisation characteristic of the single ABFC is shown in Figure 7. The cell voltage curves for various exchange current densities are shown in Figure 8.

As shown in Figure 7, with increasing current densities the ABFC voltage falls and concomitantly degrades the efficiency. Whereas, the power density at first increases to a maximum value and thereafter decreases with respect to the current density. Hence, there should be a trade-off between the power density and efficiency. This is very critical while 
designing the portable and stationary applications. In Figure 8 , the voltage curves are shown for different exchange current densities which depend on the temperature. It means that, at higher temperatures the ABFC voltage drops.

Figure 9 and Figure 10 show the P-V and I-V characteristics at $25^{\circ} \mathrm{C}$ with different irradiation levels. Figure 11 shows the MPP tracking at $\mathrm{t}=4 \mathrm{sec}$ for $300 \mathrm{w} / \mathrm{sq} . \mathrm{m}$ to $600 \mathrm{w} / \mathrm{sq} . \mathrm{m}$ irradiation change and also $600 \mathrm{w} / \mathrm{sq} . \mathrm{m}$ to $1000 \mathrm{w} / \mathrm{sq} . \mathrm{m}$ irradiation change at $\mathrm{t}=6 \mathrm{sec}$. The P\&O MPPT algorithm is effective for tracking the rated power of $30 \mathrm{~W}$. It is also observed that, the tracking speed of MPP is good with this algorithm.

Table 3. QBC specifications

\begin{tabular}{cc}
\hline \multicolumn{2}{c}{ Fuel cell stack } \\
\hline Voltage & $19 \mathrm{~V}$ \\
Current & $1.579 \mathrm{~A}$ \\
Power rating & $30 \mathrm{~W}$ \\
\hline Boost converter & \\
\hline $\mathrm{V}_{\text {in }}$ & $18 \sim 27 \mathrm{~V}$ \\
$\mathrm{~L}$ & $100 \mu \mathrm{H}$ \\
$\mathrm{C}$ & $0.2 \mu \mathrm{F}$ \\
$\mathrm{f}_{\mathrm{sw}}$ & $50 \mathrm{kHz}$ \\
$\mathrm{V}_{\mathrm{O}}$ & $35 \mathrm{~V}$ \\
\hline Quadratic buck converter \\
\hline Parameter & Nominal value \\
\hline $\mathrm{V}_{\text {in }}$ & $19 \sim 35 \mathrm{~V}$ \\
$\mathrm{~L}_{1}$ & $1.84 \mu \mathrm{H}$ \\
$\mathrm{L}_{2}$ & $0.21 \mu \mathrm{H}$ \\
$\mathrm{C}_{1}$ & $22 \mu \mathrm{F}$ \\
$\mathrm{C}_{2}$ & $1.64 \mathrm{mF}$ \\
Schottky FVD forwarvoltage drop & $0.30 \mathrm{~V}$ \\
$\mathrm{f}_{\text {sw }}$ & $300 \mathrm{kHz}$ \\
Load Rmin & $0.0333 \Omega$ \\
Load $\mathrm{R}_{\max }$ & $0.2 \Omega$ \\
Output voltage & $1 \mathrm{~V}$ \\
Output power & $30 \mathrm{~W}$ \\
\hline
\end{tabular}

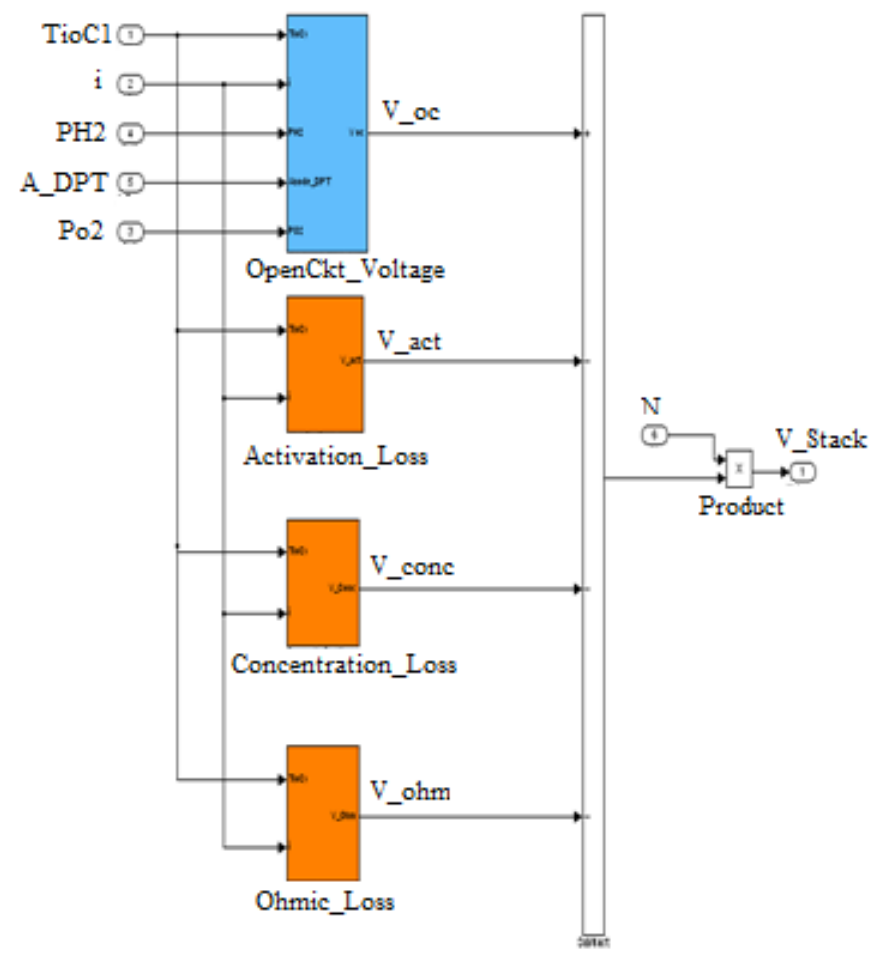

Figure 6. MATLAB model of ABFC

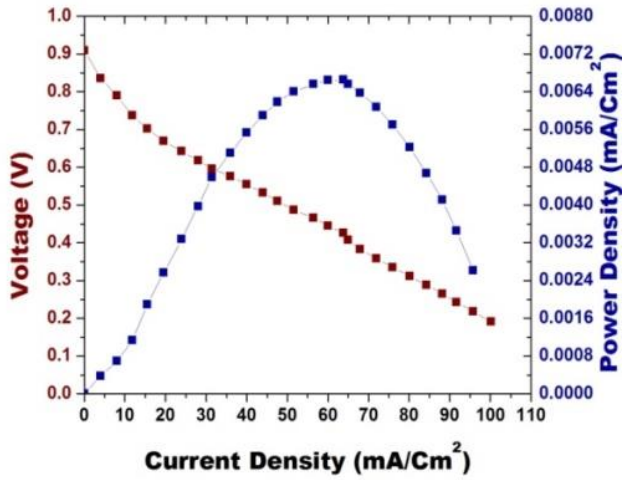

Figure 7. ABFC polarisation characteristic

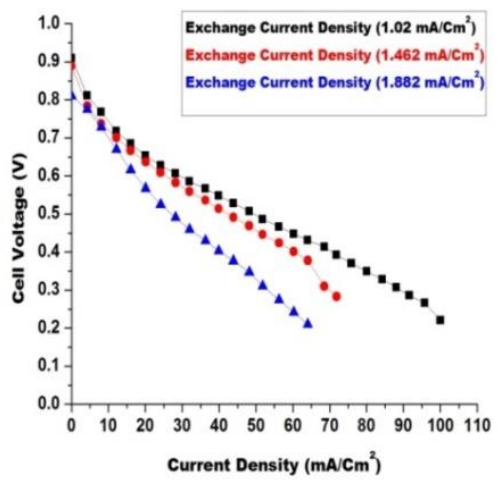

Figure 8. ABFC cell voltage curve at various exchange current densities

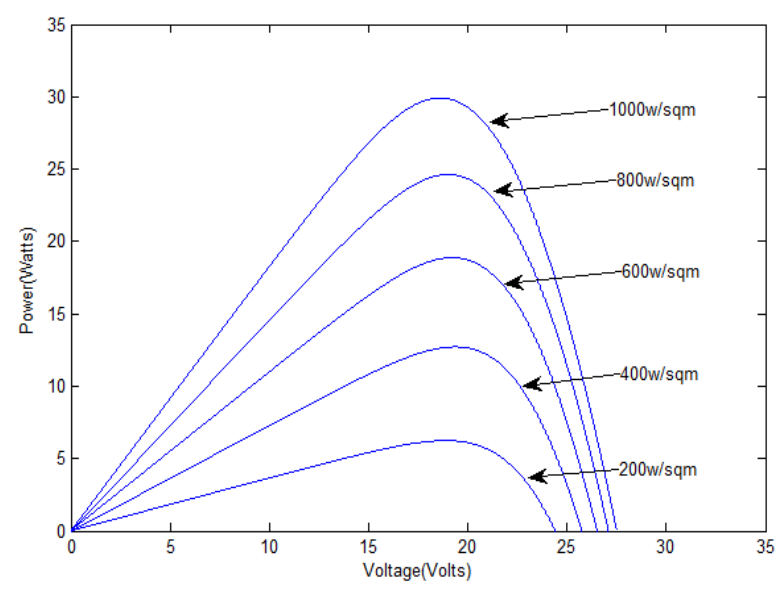

Figure 9. P-V characteristics

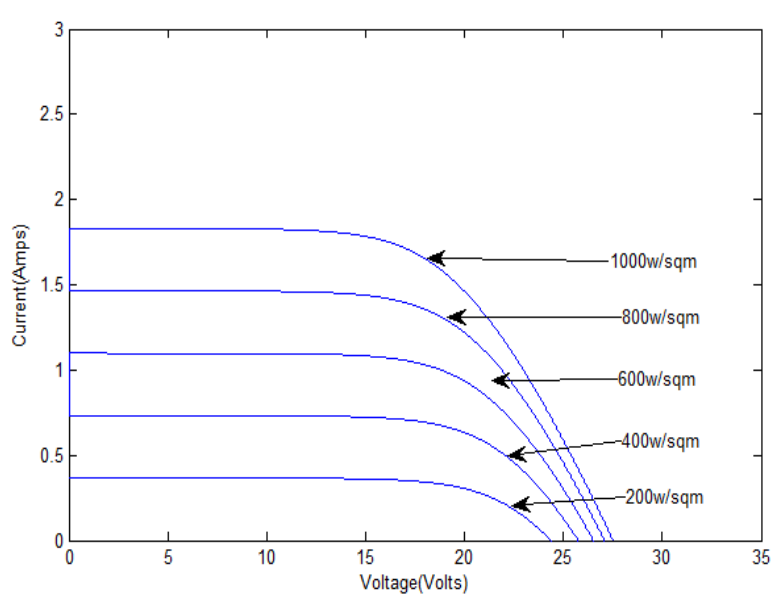

Figure 10. I-V characteristics 


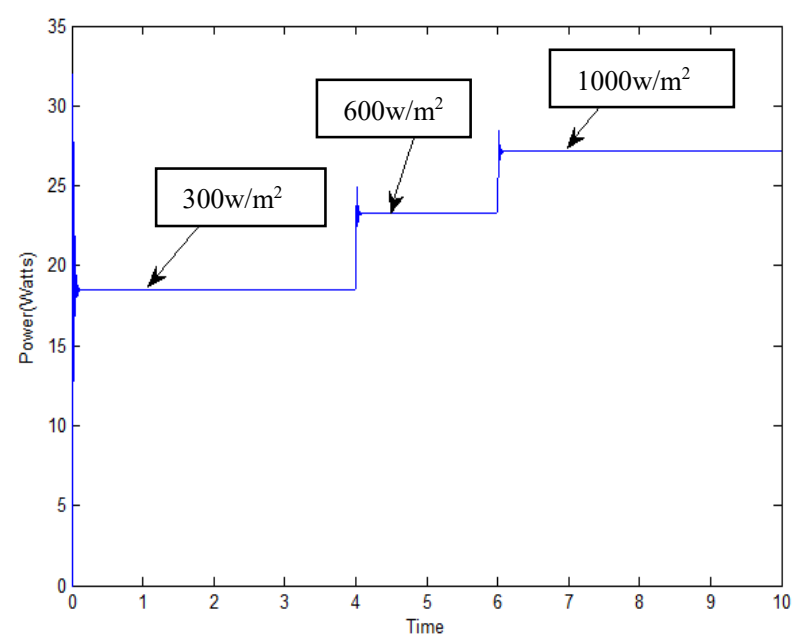

Figure 11. MPP tracking for three different irradiations using P\&O MPPT algorithm

\subsection{Power conditioning unit}

4.2.1 Controller performance at a stack voltage of $18.665 \mathrm{~V}$ with step load change

The transfer functions (TF) of filter in current loop, current loop compensator and voltage loop compensator are given in Eq. (26), Eq. (27) and Eq. (28).

The current feedback loop low pass filter TF is obtained as:

$$
F(s)=\frac{12600}{(s+12600)}
$$

The PI controller TF in current loop is obtained as

$$
\mathrm{C}_{1}(\mathrm{~s})=\frac{100(1+0.02 \mathrm{~s})}{\mathrm{s}}
$$

The PI controller TF in voltage loop is obtained as

$$
\mathrm{C}_{2}(\mathrm{~s})=\frac{20(1+0.1 \mathrm{~s})}{\mathrm{s}}
$$

The compensator design is fulfilled in MATLAB/siso tool. The corner frequency of low pass filter is equal to $300 \mathrm{kHz}$. The crossover frequency of current loop (bandwidth) is greater than the voltage loop. The current and voltage loops have gain margin $(\mathrm{GM})$ and phase margin $(\mathrm{PM})$ of $6.32 \mathrm{~dB}$, $46.7^{\circ} \& 23.7 \mathrm{~dB}, 48.7^{\circ}$ ensuring a stable system.

As shown in Figure 12, ABFC stack voltage is given as input to QBC and at $40 \mathrm{~m} \mathrm{sec}$ for 5A -30A step load. The observed transient voltage deviation is $28 \%$ with a settling time of $0.75 \mathrm{msec}$. Moreover, each fuel cell undergoes a voltage reduction from $0.889 \mathrm{~V}$ to $0.565 \mathrm{~V}$, the fuel cell stack voltage reduces from $29.337 \mathrm{~V}$ to $18.645 \mathrm{~V}$.

4.2.2 Controller performance for periodic load change at a fuel cell stack voltage of $18.665 \mathrm{~V}$

As shown in Figure 13, during load decrease (30A-5A) the transient output voltage rise is $25 \%$ with a settling time of 1.5 $\mathrm{msec}$, and $28 \%$ voltage dip during step load increase (5A$30 \mathrm{~A}$ ) having a settling time of $0.75 \mathrm{msec}$. Moreover, ABFC voltage increases from $0.565 \mathrm{~V}$ to $0.889 \mathrm{~V}$ and vice-versa, the fuel cell stack voltage increases from $18.645 \mathrm{~V}$ to 29.337 $\mathrm{V}$ and vice-versa.

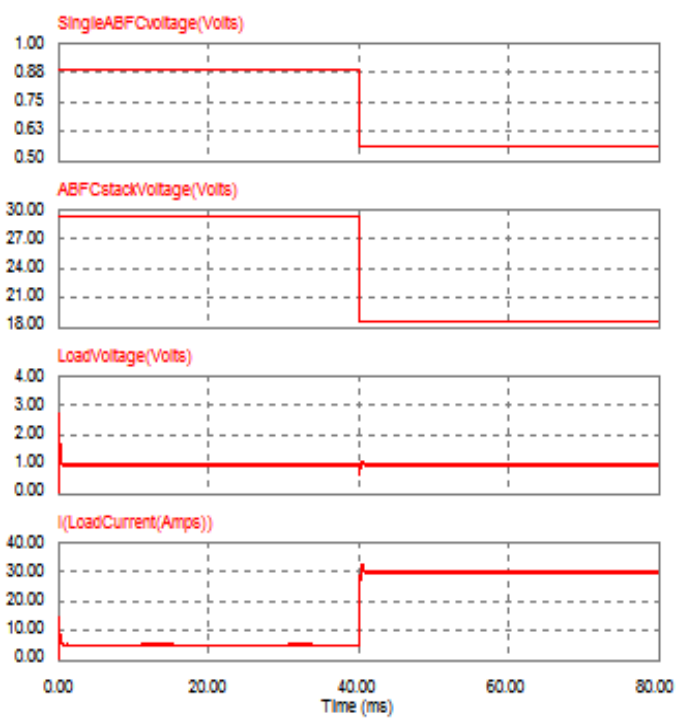

Figure 12. QBC input and output waveforms

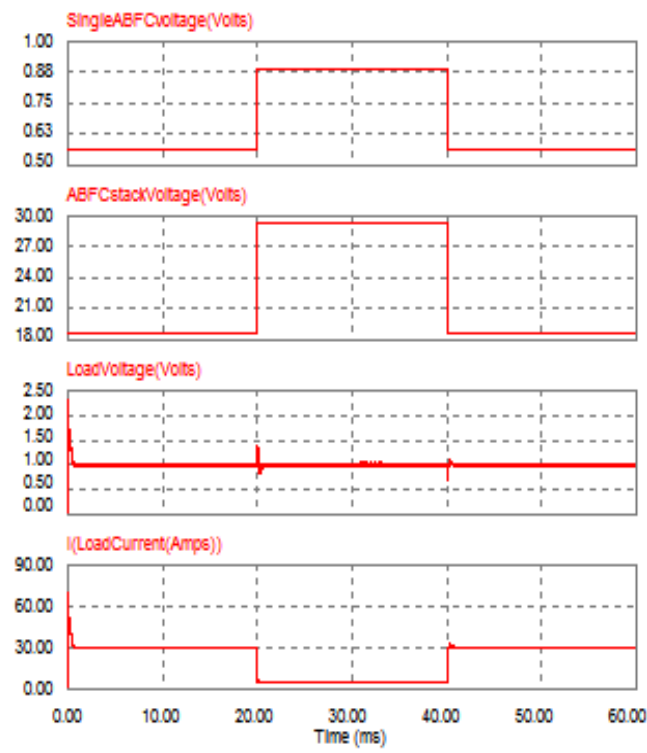

Figure 13. QBC input and output waveforms

During step increase in load from 5A-30A, the ABFC stack voltage decreases from $29.337 \mathrm{~V}$ to $18.645 \mathrm{~V}$ due to more voltage drop across the ohmic resistance $\left(R_{\text {ohmic }}\right)$ and vice-versa.

\subsection{Efficiency analysis of QBC}

Normally, the power diodes exhibit more forward voltage drop (FVD) of around 1V. Therefore, their usage can degrade the QBC efficiency due to more conduction losses. This problem can be overcome by using schottky diodes of low FVD (around $0.3 \mathrm{~V}$ ) in place of power diodes. But still the obtained efficiencies are not up to the mark in case of low voltage and high current applications. The other viable solution is the adoption of Synchronous Rectification (SR). As shown in Figure 5, the schottky diode $\mathrm{D}_{3}$ is replaced by a 
power MOSFET having very low on-state resistance $\left(\mathrm{R}_{\text {on }}\right)$ in order to achieve a remarkable QBC efficiency [12]. Figure 14 shows the efficiency comparison of QBC without and with SR, also fuel cell stack voltage for different load currents.

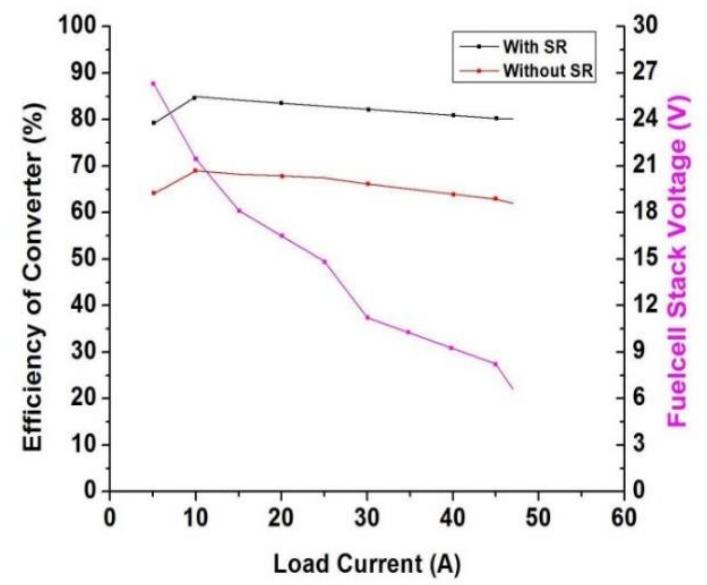

Figure 14. The efficiency of QBC and fuel cell stack voltage

At rated input voltage of $19 \mathrm{~V}$, without SR, the efficiency is found to be $65.20 \%$. With SR, the lower power MOSFET incorporated in place of $\mathrm{D}_{3}$ has a very low $\mathrm{R}_{\text {on }}$ of $1.88 \mathrm{~m} \Omega$ and the efficiency is found to be $81.90 \%$. The SR enhances the converter efficiency by $16.70 \%$.

\subsection{Efficiency of ABFC and PV Cell}

The ABFC theoretical efficiency of $83.0 \%$ is obtained by:

$$
\eta_{\mathrm{FC}}=\frac{\mathrm{V}_{\mathrm{Cell}}}{1.482}
$$

With SR the theoretical $\eta_{\max }$ is $67.97 \%$, and without SR the $\eta$ is $54.116 \%$. The efficiencies of buck and boost converter are found to be $91.4 \%$ and $91.9 \%$, the PV cell theoretical $\eta$ is $30.0 \%$. At rated load, PV module power system theoretical $\eta$ with SR is found to be $25.116 \%$.

\section{CONCLUSIONS}

In this paper the modelling of Air Breathing Fuel Cell (ABFC) and solar PV based power system is presented. In ABFC power system the QBC is implemented with ACM control strategy and the simulation results associated with step load as well as periodic load are highlighted. For step load change, ABFC as well as stack voltage decreases to 0.33 $\mathrm{V}$ and $10.68 \mathrm{~V}$. At rated load without and with SR, the theoretical $\eta_{\max }$ of ABFC power system are $54.116 \%$ and $67.97 \%$. The SR enhances ABFC system $\eta$ by $13.854 \%$. In $\mathrm{PV}$ module power system at $25^{\circ} \mathrm{C}$ with different irradiation levels the boost converter effectively tracks the maximum power. At rated load, the overall PV module PS $\eta$ is found to be $25.116 \%$. Even though low efficiencies are obtained in case of ABFC as well as solar panel, the important aspect is that they are the inexhaustible sources of energy.

\section{REFERENCES}

[1] Souleman, N.M., Olivier, T., Louis, A.D. (2012).
Development of a generic fuel cell model: application to a fuel cell vehicle simulation. International Journal of Power Electronics, 4(6): 505-522. https://doi.org/10.1504/IJPELEC.2012.052427

[2] Kumar, M.P., Kumar, A.K. (2010). Effect of cathode channel dimensions on the performance of an airbreathing PEM fuel cell. International Journal of Thermal Sciences, 49(5): 844-857. https://doi.org/10.1016/j.ijthermalsci.2009.12.002

[3] Jia, J., Li, Q., Wang, Y., Cham, Y.T., Han, M. (2009). Modeling and dynamic characteristic simulation of proton exchange membrane fuel cell. IEEE Trans. Control Syst. Technol., 24(16): 283-291. https://doi.org/10.1109/TEC.2008.2011837

[4] Standford, E. (2003). Power technology roadmap for microprocessor voltage regulators. In: Proc. PSMA, Feb. 2003.

[5] Xie, X.G., Qian, Z.M. (2008). A new two-stage buck converter for voltage regulators. Power Electronics Specialists Conference (PESC), Rhodes, Greece, pp. 1580-1584.

https://doi.org/10.1109/PESC.2008.4592164

[6] Ajayan, S., Selvakumar, I.A. (2020). Modeling and simulation of PEM fuel cell electric vehicle with multiple power sources. International Journal of Recent Technology and Engineering, 8(6): 2967-2975. https://doi.org/10.35940/ijrte.F8420.038620

[7] Amphlett, J.C., Baumertr, M., Mannr, F. (1995). Performance modeling of the Ballard mark IV solid polymer electrolyte fuel cell: Empirical model development. Journal of The Electrochemical Society, 142(1): 9-15. https://doi.org/10.1149/1.2043959

[8] Kim, J., Lees, M., Srinivasan, S. (1995). Modelling of proton exchange membrane fuel cell performance with an empirical equation. Journal of the Electrochemical Society, $\quad$ 142(8): 2670-2674. https://doi.org/10.1149/1.2050072

[9] Tagore, R.Y., Anuradha, K., Babu, V.A.R., Kumar, M.P. (2019). Modelling, simulation and control of fuel cell powered laptop computer voltage regulator module. International Journal of Hydrogen Energy, 44(21): 11012-11019. https://doi.org/10.1016/j.ijhydene.2019.02.141

[10] Ganesh, G., Kumar, V.G., Babu, V.A.R., Rao, S.G., Tagore, R.Y. (2015). Performance analysis and MPPT control of a standalone hybrid power generation system. Journal of Electrical Engineering, 15(1): 334-343.

[11] Yadlapalli, R.T., Narasipuram, R.P., Kotapati, A. (2020). An overview of energy efficient solid state LED driver topologies. International Journal of Energy Research, 44(2): 612-630. https://doi.org/10.1002/er.4924

[12] Yadlapalli, R.T., Kotapati, A. (2014). A fast-response sliding-mode controller for quadratic buck converter. International Journal of Power Electronics (IJPELEC), 6(2):

103-130. https://doi.org/10.1504/IJPELEC.2014.061468

\section{NOMENCLATURE}

$\mathrm{V}$

A

$\Delta \mathrm{V}$
Voltage, $\mathrm{V}$

Active area of cell, $\mathrm{cm}^{2}$

Overpotential, V 
Gaseous constant, J/mol K

Faraday's constant, $\mathrm{C} / \mathrm{mol}$

Partial pressure of hydrogen, bar

Pressure of hydrogen, bar

Saturation pressure of water, bar

Current density, $\mathrm{mA} / \mathrm{cm}^{2}$

Crossover current, $\mathrm{mA} / \mathrm{cm}^{2}$

Limiting current density, $\mathrm{mA} / \mathrm{cm}^{2}$

Exchange current density, $\mathrm{mA} / \mathrm{cm}^{2}$

Ohmic resistance, $\Omega-\mathrm{cm}^{2}$

Thickness of membrane, $\mathrm{cm}$

Temperature, $\mathrm{K}$

Boltzmann's constant, $\mathrm{J} / \mathrm{K}$

Current, A

Charge of electrons, $\mathrm{C}$

Ideality factor

Energy gap, eV
$\mathrm{K}_{\mathrm{i}}$

D

C

$\mathrm{L}$

$\mathrm{f}_{\mathrm{sw}}$

\section{Greek letters}

Number of cells

Solar irradiation, $\mathrm{W} / \mathrm{m}^{2}$

Rated power

Short-circuit current temperature coefficient

Duty cycle

Capacitor, F

Inductor, $\mathrm{H}$

Switching frequency, $\mathrm{Hz}$

Charge transfer coefficient

Water drag coefficient

Conductivity of membrane, $\mathrm{S} / \mathrm{cm}$

Specific resistance, $\Omega$-cm 